DOI:10.2478/cpp-2018-0010

\title{
An overlooked issue: sexual dysfunctions in men addicted to alcohol
}

Przemilczany problem: dysfunkcje seksualne u mężczyzn uzależnionych od alkoholu

Jakub Siembida ${ }_{\mathrm{A}, \mathrm{B}, \mathrm{C}, \mathrm{D}, \mathrm{E}, \mathrm{F}}$ Piotr Frończuk ${ }^{2} \mathrm{C}, \mathrm{D}, \mathrm{E}, \mathrm{F}$,

Justyna Morylowska-Topolska ${ }^{3} \mathrm{C}, \mathrm{D}, \mathrm{E}, \mathrm{F}$, Aleksandra $\operatorname{Siek}^{4} \mathrm{C}, \mathrm{D}, \mathrm{E}, \mathrm{F}$,

\section{Hanna Karakuła - Juchnowicz ${ }^{5}, \mathrm{D}, \mathrm{E}, \mathrm{F}$}

${ }^{1}$ Student Research Group at the I Department of Psychiatry, Psychotherapy and Early Intervention, Medical University of Lublin

${ }^{2}$ Non-public Healthcare Center, Mental Health Outpatient Department, Biała Podlaska

${ }^{3}$ Department of Clinical Neuropsychiatry, Medical University of Lublin

${ }^{4}$ Department of Psychiatry, Municipal Hospital SPZOZ in Siedlce

${ }^{5}$ I Department of Psychiatry, Psychotherapy and Early Intervention, Medical University of Lublin

\section{Introduction}

According to the data obtained in the EZOP Poland study (2015), the prevalence of alcohol dependence in lifetime in Poland amounts to about $2.2 \%$ of the population, entailing enormous social, family and personal harm, including health damage. It is estimated that about $72 \%$ of alcohol-dependent patients complain about one or more problems related to the sexual sphere, which may result from both the development of somatic complications in the course of alcohol dependence, and from psychiatric complications that themselves can lead to sexual dysfunction. There are reports and clinical observations indicating that the occurrence of sexual dysfunction (SD) can affect the shortening or interruption of the period of abstinence.

\section{Aim}

The aim of this work is to show sexual dysfunctions in alcohol-dependent men and to discuss the factors that may affect the occurrence of the above-mentioned dysfunctions.

\section{Material and methods}

The available literature was reviewed using Medline, Google Scholar and ScienceDirect browsers by entering the keywords: alcohol dependence, sexual dysfunction, comorbidity, alcohol-caused diseases and time descriptors: 1979-2016.

Results

- Alcohol dependence is associated with the occurrence of various types of sexual dysfunctions (SD).

- The diagnosis of SD should take into account all possible causes that may lead to the development of SD in this group of patients, including the comorbidity of somatic diseases or the negative impact of drugs on sexual function.

- Occurrence of SD is connected with a higher risk of abstinence interruption.

- There is a need to carry out more research in order to better understand the relationship between alcohol dependence and the prevalence of sexual dysfunctions.

Keywords: alcohol dependence, sexual dysfunction, comorbidity, alcohol-caused diseases

\section{Wstęp}

Rozpowszechnienie uzależnienia od alkoholu w ciągu życia wśród polskiej populacji wynosi ok. 2,2\%, pociągając za sobą ogromne szkody społeczne, rodzinne i osobiste, w tym zdrowotne. Szacuje się, że ok. 72\% pacjentów uzależnionych od alkoholu skarży się na jeden lub więcej problemów związanych ze sferą seksualną, które mogą wynikać zarówno z rozwoju powikłań somatycznych 
w przebiegu uzależnienia od alkoholu, jak i powikłań psychiatrycznych, które same w sobie mogą prowadzić do wystąpienia zaburzeń seksualnych. Istnieją doniesienia i obserwacje kliniczne wskazujące, iż wystąpienie dysfunkcji seksualnych (DS) może wpływać na skrócenie lub przerwanie okresu abstynencji.

\section{Cel}

Celem niniejszej pracy jest przedstawienie dysfunkcji seksualnych występujących u mężczyzn uzależnionych od alkoholu oraz omówienie czynników mogących wpłynąć na występowanie wyżej wymienionych dysfunkcji.

\section{Materiał i metoda}

Dokonano przeglądu dostępnej literatury korzystając z baz bibliograficznych: Medline, Google Scholar oraz ScienceDirect wprowadzając słowa klucze: alcohol dependence, sexual dysfunction, comorbidity, alcohol caused diseases oraz deskryptory czasowe: 1979-2016.

\section{Rezultaty}

- Uzależnienie od alkoholu związane jest z występowaniem różnych rodzajów dysfunkcji seksualnych.

- W diagnozie DS należy brać pod uwagę wszystkie możliwe przyczyny mogące doprowadzić do rozwoju DS w tej grupie pacjentów, między innymi współwystępowanie chorób somatycznych czy negatywny wpływ leków na funkcje seksulane.

- Występowanie DS jest związane z wyższym ryzykiem przerwania abstynencji od alkoholu.

- Istnieje potrzeba przeprowadzenia większej liczby badań w celu lepszego zrozumienia związku pomiędzy uzależnieniem od alkoholu a występowaniem zaburzeń seksualnych.

Słowa kluczowe: uzależnienie od alkoholu, dysfunkcje seksualne, współchorobowość, choroby spowodowane używaniem alkoholu

\section{Introduction}

Taking into account the data presented by the Sejm Bureau of Research in 2016, alcohol in Poland is the most popular stimulant, which is used by over $80 \%$ of the population. In the same analysis, there is information that nearly 3 million Poles are risky drinkers, of whom 600,000 are alcohol-dependent individuals (2.4\% of the population) [1]. The ratio of alcohol-dependent men to women is close to 7: 1 [1]. Taking into account that nearly 200 disease entities and injuries are associated with alcohol consumption (the first place is occupied by the cardiovascular system disorders and mental disorders), the scale of health consequences associated with alcohol consumption seems enormous [2]. A group of disorders relatively rarely addressed in everyday clinical practice are sexual dysfunctions, the prevalence of which in the group of men addicted to alcohol, oscillates (depending on gender and culture community) within the range of $40-85.5 \%$ [3-7].

\section{Aim}

The aim of this work is to show sexual dysfunctions in men abusing alcohol and to discuss factors that may affect the occurrence of the above-mentioned dysfunctions.

\section{Method}

The available literature was reviewed using Medline, Google Scholar and Science Direct browsers by entering the keywords: alcohol dependence, sexual dysfunction, comorbidity, alcohol caused diseases and time descriptors: 1979-2016.
For the sake of transparency and easier perception, the work is divided into the following sections: 1 . the pathophysiology of sexual dysfunctions in men dependent on alcohol, 2. the classification of the abovementioned dysfunction, 3. the diseases and disorders associated with alcohol dependence and their potential role in the development of sexual dysfunctions will be discussed, including 3.1. somatic disorders: hypertension, diabetes, cirrhosis and neurological disorders, 3.2. mental disorders: depression and anxiety disorders.

\section{The pathophysiology of sexual dysfunctions in men dependent on alcohol}

Sexual dysfunctions may have a complex basis and may result from changes in three systems: I. the vascular system, II. the disorders in the nervous-hormonal system and III. resulting from the direct reaction of alcohol and its metabolites on the gonads [8]. According to the pathomechanism within the circulatory system, the synthesis of nitric oxide (NO) having vasodilating effect, is impaired. As a consequence, blood vessels of the penis do not fill up with blood, which prevents the erection $[9,10]$. In the second, neural-hormonal aspect, the hypothalamicpituitary-gonadal axis is impaired, which results in the reduction of production of testosterone by the testes, of $\mathrm{LH}$ (luteinizing hormone) by the pituitary gland and of GnRH (hypothalamic gonadoliberine) by the hypothalamus [1113]. An additional source of disorders related to alcohol is the direct, damaging effects of ethanol and acetic aldehyde on the testicles. These substances contribute to the formation 
of reactive oxygen forms that damage the testicle cells, thus contributing to lower testosterone levels $[14,15]$.

\section{Classification of sexual dysfunctions}

The classification of sexual dysfunctions is based on the International Statistical Classification of Diseases and Health Problems ICD-10 [16]. Sexual dysfunctions not caused by organic disorders or somatic disease are included in behavioral syndromes associated with physiological disorders (coded as F.52.0) [16]. Additionally, in the ICD-10 classification, sexual dysfunctions in alcohol dependency can be coded in the category of "Alcohol dependence with other alcohol-induced disorders" (F10.28) and with annotations about the type of sexual dysfunction [16] . Worth noting is also the fact that in the DSM-5 classification of mental disorders by the American Psychiatric Association there are included sexual dysfunctions caused by the use of psychoactive substances as a separate diagnostic category [17].

Another issue is the assessment of the prevalence of sexual dysfunctions in people dependent on alcohol: few studies are available, usually based on a small population of respondents; and those that are already available do not include comorbidities in this group of patients $[4,18]$.

Nevertheless, we decided to mention them in order to present the characteristics of individual sexual dysfunctions of the F52 category and to show the scale of the problem. The following classification according to ICD-10 also seems appropriate due to its universality, as very often there are different divisions and classifications of disorders according to different societies.

\section{F52.0 - Lack or loss of sexual desire}

The lack of sexual desire is a basic symptom and not secondary to other sexual problems, such as erectile dysfunction or dyspareunia [16]. The percentage of alcoholdependent patients affected by this condition varies from 36 to $70 \%[4,18]$.

\section{F52.1 - Sexual aversion disorder and lack of sexual pleasure}

The prospect of sexual contact is accompanied by such anxiety that the patient avoids sexual activity (aversion) or sexual reactions run normally, the orgasm is available, but the patient does not experience adequate pleasure (lack of sexual pleasure) [16]. It is estimated that the disorder affects approximately $15 \%$ of alcohol-dependent men [18].

\section{F52.2 - Lack of genital response}

It is estimated that the lack of genital response affects about $33 \%$ of alcohol-dependent subjects [15]. It is defined as a permanent or recurrent, partial or complete inability to achieve or maintain erection until the end of sexual intercourse [16]. In people struggling with alcohol dependence and erectile dysfunction, problems with getting erection are more frequently observed (59.3\%) than with maintaining it (40.6\%) [18]. In addition, Arackal et al. in their study note that in $8 \%$ of patients orgasm is felt while the erection is not maintained [18].

\section{F52.3 - Orgasmic disorders}

This group includes sexual dysfunctions in the course of which orgasm is absent or delayed [16]. Among alcohol-dependent people, the prevalence of this disorder is estimated at 10 to $25 \%[4,18]$.

\section{F52.4 - Premature ejaculation}

This is inability to control ejaculation to the extent that it is sufficient for both partners to be satisfied with sexual intercourse. [16]. This is the most common sexual dysfunction occurring among alcohol-dependent subjects, and its prevalence is estimated from $38 \%$ to even $86 \%$ $[4,18]$.

\section{F52.6 - Dyspareunia of inorganic origin}

Dyspareunia (pain during intercourse) occurs in both women and men, it is often caused by a local pathological condition and should then be properly qualified [16]. The diagnosis of inorganic dyspareunia should be used only when there is no other primary sexual dysfunction. It is the least frequent sexual dysfunction, which occurs in about $6 \%$ of patients dependent on alcohol $[4,18]$.

Additionally, in the study of Arackal and Benegal it was shown that $48 \%$ of respondents reported more than one sexual dysfunction [18]. Interestingly, in this study a linear correlation was found between the amount of alcohol consumed by the subjects and the number of sexual dysfunctions. The relationship between the occurrence of sexual dysfunctions and the amount of alcohol consumed can also be seen in the studies of Van Thiel and Lester

\section{Diseases associated with alcohol dependence and sexual dysfunctions}

\subsection{Somatic diseases Hypertension}

While analyzing diseases development of which increases the risk of sexual dysfunctions, we can distinguish such disorders that are determined by alcohol abuse. An example of such a disease is hypertension. In the literature of the subject there are numerous hypotheses taken into account related to the mechanism of alcohol involvement in the development of hypertension: induction of hypertension due to alcohol reaction on the central nervous system [20], 
reduction of reflexes from the baroreceptors [21], increase in the sympathetic system [22], increased activation of the renin-angiotensin-aldosterone system [23-25], increase in cortisol concentration in alcohol abusers [26,27], increase in intracellular calcium ion concentration [28], dysfunction in vascular endothelium [29]. In the context of the present work, the last hypothesis seems to be the most interesting. It assumes that alcohol intensifies the synthesis of angiotensin II having vasoconstriction activity and inhibits the activity of endothelial nitric oxide synthetase (eNOS). As a result of these mechanisms, vasoconstriction and blood pressure increase occur [29 - 32]. This hypothesis is coherent with the hypothesis of the development of sexual dysfunction in people addicted to alcohol being a disorder of the NO synthesis by the penis vascular endothelium. The relationship between sexual dysfunction and hypertension is also interesting. Even $68 \%$ of patients with hypertension have sexual dysfunctions [33-36], and the occurrence of such dysfunctions is a potential predictor of adverse cardiovascular events in highrisk patients [37]. In addition, alcohol consumption shows a linear correlation with an increased risk of developing hypertension [38]. According to the guidelines of the Polish Association of Arterial Hypertension, the consumption of pure ethanol should not exceed the limit of 20-30 g (2-3 standard doses of alcohol) in men per day [39]. Taking into account the previously mentioned reports of Van Thiel and Lester [19], it is clear that exceeding the daily intake of 30 $\mathrm{g}$ of pure ethanol daily predisposes to the development of both hypertension and sexual dysfunctions. Unfortunately, there are no studies covering both these elements as predictors of the development of sexual dysfunctions in alcohol-dependent people. It is also difficult to determine if there is a relationship between the development of sexual dysfunctions in alcoholics who have hypertension at the same time.

\section{Diabetes}

Type 2 diabetes is a disorder that affects the normal metabolism of glucose in the body. Reduced muscle and other vitals sensitivity to insulin is responsible for this, which is associated with impaired insulin secretion by pancreatic $\beta$ cells [40]. Diabetes is responsible for the whole range of diseases such as nephropathy and diabetic retinopathy, and also contributes to the development of sexual dysfunction (as a result of vascular changes occurring in diabetes, but most of all neuropathy) [41]. Sexual dysfunctions affect approximately $50-70 \%$ of people with type 2 diabetes [42]. At the same time, severe alcohol abuse predisposes to the development of diabetes [43]. The cause - effect chain is like in hypertension: alcohol itself causes sexual dysfunctions and at the same time predisposes to diseases that can cause sexual dysfunctions. Unfortunately, this is only a hypothesis, because there is no research confirming the existence of such relationships.

\section{Cirrhosis of the liver}

The relationship between alcohol abuse and cirrhosis is commonly known. According to the study by Rehm et al., alcohol consumption exceeding 3 standard doses of alcohol (calculated per one dose $=12 \mathrm{~g}$ ethanol) significantly affects the development of cirrhosis of the liver [44]. In another study conducted by Sherlock et al., cirrhosis affects about $77 \%$ of the alcohol abusers [45]. Liver damage by alcohol is associated with its ability to metabolize ethanol. It is oxidised twice (initially to acetaldehyde and then to acetic acid), which is accompanied by the accumulation of a large amount of reduced NAD (NADH), which in turn disturbs the oxidative and metabolic capacity of the liver. Excess of NADH promotes the synthesis and deposition of triglycerides in the liver. This leads to the development of the first stage of alcoholic liver disease, which is steatosis [46-48]. Then, as a result of continued chronic ethanol intake, chronic hepatitis occurs (stage 2), resulting in fibrosis of the organ and in the final stage may lead to its cirrhosis (stage 3) [49]. Cirrhosis of the liver contributes to the development of other diseases, including sexual dysfunctions, the prevalence of which in this group of patients is estimated at about 51\% [50]. It is a consequence of metabolic liver failure, which is manifested in three aspects. First, metabolic failure of the organ results in the accumulation of harmful substances (including alcohol and its metabolites), which directly damage the hypothalamus, pituitary gland and gonads. Secondly, hyperestrogenism and a reduced androgens-estrogens ratio resulting from failure of portal circulation and increased conversion of androgens to peripheral estrogens. Thirdly, impaired synthesis of albumin in the liver, resulting in deficiency of proteins necessary for the synthesis of hormones of the anterior pituitary [51-54]. For these reasons, there is a visible decrease in serum testosterone in people treated for alcoholic cirrhosis [55].

The cause - effect sequence between harmful alcohol abuse, cirrhosis and sexual dysfunctions seems to be evident.

\section{Neurological diseases}

Another group of disorders affecting people dependent on alcohol are neurological diseases, among which two main groups of diseases can be distinguished: alcohol polyneuropathy and alcohol encephalopathies (Wernicke encephalopathy, Morel's laminar sclerosis, or central pontine myelinolysis] [56]. The etiology of these diseases is associated with deficiency of thiamine. Three factors account for this deficiency: insufficient supply, impaired absorption in the small intestine and 
functional insufficiency of the liver (as a result of which thiamine is phosphorylated to its active form) [57]. It is also worth emphasizing that polyneuropathy is also one of the frequent complications of diabetes, which, as has already been described, is more common in people who consume excessive amounts of alcohol. In addition, people who have discontinued alcohol consumption may experience withdrawal seizures ("alcoholic epilepsy"). The pathomechanism of convulsions may be attributed to the reduced sensitivity of GABAergic receptors and increased activity of the stimulating amino acid system (NMDA receptors) [58,59].

It has been shown that neuropathies or epilepsy are factors that can predispose to sexual dysfunction [60]. The prevalence of neuropathy among alcoholics is estimated at around $25-66 \%$ [61]. Hence, the conclusion that in some men addicted to alcohol, the development of sexual dysfunctions may be attributed to neuropathy developed on the basis of excessive alcohol consumption.

Lesch Type IV alcohol typology is also worth mentioning. He describes the development of alcohol dependence in people with injuries to the central nervous system that developed during the perinatal period or early childhood [62,63]. The diseases that accompany these injuries are neuropathies and epilepsy. Such people are easily influenced by the environment, the decision - making process is impaired and cognitive processes are disturbed. Taking into account this type of dependence, injuries of the nervous system in the early stages of development may be a common cause of the development of sexual dysfunctions and alcohol dependence in some patients.

\subsection{Mental disorders \\ Depressive disorders}

Based on the patients' drinking patterns and origin of substance craving, abstinence syndrome and the recommended forms of treatment according to the Lesch Typology, four subtypes of alcohol dependence can be distinguished [64]. In the context of the subject of this paper, particular attention should be paid to Type III, the model of "alcohol as an antidepressant", also called "symptomatic", "psychiatric" or "psychotic" [63]. It characterizes people craving for alcohol for the purpose of treating psychopathological symptoms that most often accompany depression. In literature, there is a significant difference in the prevalence of sexual dysfunction in people with depression (59/1000 people) compared to healthy people (37/1000) [65]. The relationship between depression and sexual dysfunctions is also worth mentioning here. Seagraves notes in his research that the occurrence of depression leads to the occurrence of sexual dysfunctions, and vice versa; some patients experienced depression, the development of which was attributed to sexual dysfunctions [66]. In addition, a depressive episode often develops in the course of alcohol dependence, which, as already mentioned, may contribute to the development of sexual dysfunctions [67]. These observations seem to be important for two reasons. First of all, it is possible that sexual dysfunction in patients representing the Lesch Type III may be due to depressive disorders rather than the strictly toxic effects of alcohol. Secondly, addiction can be the result of "selfmedication" accompanying a depressive disorder. In turn, the development of a depressive disorder may be the result of a sexual dysfunction occurring in a patient. However, our hypothesis has not found confirmation in scientific studies due to the limited literature devoted to this problem. The only clue to determine the primary cause of the problem is undoubtedly the past medical history. Interestingly, Kim and Oh's reports seem to be interesting as well. They report that people with sexual dysfunction are psychiatrically affected, have higher levels of norepinephrine in their serum, however there are no studies confirming whether this relationship is reflected in people who abuse alcohol [68]. It is possible that in the future, the assessment of noradrenaline levels may help in the diagnosis of sexual dysfunctions, the basis of which is seen in mental disorders.

Another aspect that is important in Type III of alcohol dependence is the sleep disorder. It is also a significant problem that seems to grow in people treated for withdrawal, where the percentage of patients with sleep disorders, depending on the characteristics of the group, is at $36-72 \%$ [69]. This is an important observation, because sleep disorders also predispose to sexual dysfunctions [70]. In addition, sleep disorders alone can lead to the development of alcohol dependence, which in the mechanism of the vicious circle, further aggravates sleep disorders. For these reasons, it seems important to pay attention to sleeping pattern in alcohol dependent patients, because sleep disorders may be the reason for the development of both alcohol dependence and sexual dysfunction [71 - 74].

\section{Anxiety disorders}

Lesch Type II alcohol dependence is called "anxiety model", "neurotic", "anxiety", characterizing people who consume alcohol to reduce the feeling of anxiety $[63,75]$. The incidence of this type of dependency is difficult to estimate and it is thought that in the alcohol dependent population the presence of generalized anxiety may range from 3 to $52 \%$ [76]. In addition, Lesch Type II patients demonstrate very low self-esteem and ego weakness [62]. After analyzing the availableliterature, we hypothesized that sexual dysfunctions in Lesch Type III and II patients are very similar. Similarly to Type III, in Type II it can be hypothesized that anxiety is both the reason for developing alcohol dependence and sexual 
dysfunction, or that the occurrence of sexual dysfunction is one of the factors affecting the development of sexual dysfunction, and in the longer term the alcohol dependence [77]. In the studies of Arackal and Benegal, it can be found that $19.79 \%$ of respondents stated dissatisfaction with their own sexual functions [18]. However, due to the limited scope of the conducted research it is difficult to determine how much reported dissatisfaction was reflected in actual problems, and to what extent is the low self-esteem that occurs in this type of alcohol dependence.

\section{Summary}

The currently recommended in medicine holistic approach should be reflected in the diagnosis and treatment of sexual dysfunctions in alcohol-dependent men. First of all, there is a lack of research on sexual dysfunctions in alcohol dependent people suffering from comorbidities. The analysis of current research studies suggests that the problem of dysfunction may be related to alcohol in two aspects. First of all, dysfunctions may result from direct harmful effects of alcohol, and secondly, they may be a consequence of a disease to which excessive alcohol consumption predisposed. In addition, there is a need for accurate diagnosis of sexual dysfunctions in people whose dependency can be classified as Lesch Type II or III. It is possible that depression and anxiety in such patients are primary disorders that contribute to the development of sexual dysfunctions and alcohol dependence. A probable hypothesis may be that for a part of Lesch Type II and III alcohol dependent patients, the development of alcoholism results from primary sexual dysfunctions in the mechanism of which depression and anxiety play an indirect role. However, as we stated above, to confirm this hypothesis, more comprehensive research on this subject must be carried out.

\section{Wstęp}

Biorąc pod uwagę dane przedstawione przez Biuro Analiz Sejmowych z 2016 roku alkohol jest w Polsce najpopularniejszą używką, po którą sięga ponad 80\% społeczeństwa.W tej samej analizie możemy odnaleźć informacje, że blisko $3 \mathrm{mln}$ Polaków pije ryzykownie, z czego uzależnionych jest 600 tysięcy osób (2,4\% populacji) [1]. Stosunek uzależnionych mężczyzn do kobiet wynosi blisko 7:1 [1]. Biorąc pod uwagę, że blisko 200 jednostek chorobowych i urazów związanych jest ze spożywaniem alkoholu (z czego schorzenia te dotyczą głównie układu sercowo-naczyniowego oraz zaburzeń psychicznych), skala konsekwencji zdrowotnych związanych ze spożyciem alkoholu wydaje się ogromna [2]. Grupą zaburzeń, która rzadko zwraca uwagę klinicystów w codziennej praktyce są zaburzenia seksualne, których rozpowszechnienie $\mathrm{w}$ grupie mężczyzn uzależnionych od alkoholu waha się
While mentioning the holistic approach, the treatment of comorbidities in alcohol dependent people with sexual dysfunctions is also worth taking into account. It is worth remembering in clinical practice that some hypertensive drugs can aggravate the problem of such people. As the research confirms, $\beta$-blockers, thiazides and blockers of calcium channels more often cause erectile dysfunction than convertase inhibitors or angiotensin receptor blockers [78]. There are also promising reports about the effect of Tadalafil. In the conducted studies, sexual function improvement is observed in people with alcohol cirrhosis [79]. There is a similar situation with regard to psychotropic drugs, especially from the SSRI group. Considering that patients classified into Lesch Type II and III alcohol dependence are characterized by the coexistence of anxiety and depression, sexual dysfunctions should be considered in their treatment. Therefore, following the research, it seems that a better alternative to SSRIs, where sexual dysfunctions concern 30 $60 \%$, are such drugs as buspirone or nefazodone, where the occurrence of such dysfunctions affects less than $10 \%$ of patients [80].

\section{Conclusions}

Alcohol dependence is associated with the occurrence of various types of sexual dysfunctions (SD).

The diagnosis of SD should take into account all possible causes that may lead to the development of SD in this group of patients, including the comorbidity of somatic diseases or the negative impact of drugs on sexual function.

Occurrence of SD is connected with a higher risk of abstinence interruption.

There is a need to carry out more research in order to better understand the relationship between alcohol dependence and the prevalence of sexual dysfunctions.

(w zależności od płci i kręgu kulturowego) w granicach od 40 do $85,5 \%$ [3 - 7].

Cel

Celem niniejszej pracy jest przedstawienie dysfunkcji seksualnych występujących u mężczyzn uzależnionych od alkoholu oraz omówienie czynników mogących wpłynąć na występowanie wyżej wymienionych dysfunkcji.

\section{Metoda}

Dokonano przeglądu dostępnej literatury korzystając z baz bibliograficznych: Medline, Google Scholar oraz ScienceDirect wprowadzając słowa klucze: alcohol dependence, sexual dysfuntion, comorbidity, alcohol caused diseases oraz deskryptory czasowe: 1979-2016.

Celem uzyskania przejrzystości praca została podzielona na podrozdziały, które kolejno obejmują: 
1.patofizjologię dysfunkcji seksualnych u mężczyzn uzależnionych od alkoholu, 2. klasyfikację ww. dysfunkcji. Następnie zostały omówione 3. choroby oraz zaburzenia towarzyszące uzależnieniu od alkoholu oraz ich potencjalna rola w rozwoju dysfunkcji seksualnych, w tym 3.1 . zaburzenia somatyczne: nadciśnienie tętnicze, cukrzyca, marskość wątroby oraz schorzenia neurologiczne, z kolei w drugiej 3.2. zaburzenia psychiczne: zaburzenia depresyjene oraz lękowe.

\section{Patofizjologia dysfunkcji seksualnych u mężczyzn uzależnionych od alkoholu}

Dysfunkcje seksualne mogą mieć złożone podłoże i wynikają ze zmian w obrębie trzech układów: I. dotyczącym układu naczyniowego, II. jako zaburzenia w obrębie układu nerwowo-hormonalnego oraz III. wynikającym z bezpośredniego działania alkoholu i jego metabolitów na gonady [8]. Patofizjologiczne zmiany w obrębie układu krwionośnego zakładają upośledzenie syntezy tlenku azotu (NO) działającego wazodylatacyjnie. W konsekwencji naczynia krwionośne prącia nie napełniają się odpowiednio krwią, co uniemożliwia osiągnięcie wzwodu $[9,10]$. W drugim, nerwowo-hormonalnym ujęciu zaburzeniu ulega oś podwzgórze-przysadka-gonady, co powoduje zmniejszenie produkcji testosteronu przez jądra, LH (hormonu luteizującego) przez przysadkę oraz GnRH (podwzgórzowej gonadoliberyny) przez podwzgórze [1113]. Dodatkowym źródłem zaburzeń u osób uzależnionych od alkoholu jest bezpośrednie, uszkadzające działanie etanolu jak i aldehydu octowego na jądra. Substancje te przyczyniają się do tworzenia reaktywnych form tlenu (RFT), które uszkadzając komórki jąder przyczyniają się tym samym do obniżenia stężenia testosteronu[14,15].

\section{Klasyfikacja dysfunkcji seksualnych}

Klasyfikacja zaburzeń seksualnych opiera się na Międzynarodowej Statystycznej Klasyfikacji Chorób i Problemów Zdrowotnych ICD-10 [16]. Dysfunkcje seksualne nie spowodowane zaburzeniami organicznymi ani chorobą somatyczną zaliczono do zespołów behawioralnych związanych z zaburzeniami fizjologicznymi (kodowane jako F.52) [16]. Dodatkowo w klasyfikacji ICD-10 dysfunkcje seksualne u osób uzależnionych od alkoholu powstałe w związku z uzależnieniem można kodować w kategorii uzależnień jako „zespół uzależnienia spowodowany używaniem alkoholu z ..." (F10.28) oraz dodać adnotację dotyczącą rodzaju dysfunkcji seksualnej [16]. Warty uwagi wydaje się także fakt, że w klasyfikacji zaburzeń psychicznych Amerykańskiego Towarzystwa Psychiatrycznego DSM-5 uwzględniono dysfunkcje seksualne wywołane używaniem substancji psychoaktywnych jako oddzielną kategorię diagnostyczną [17].
Kolejną kwestią jest problem związany z oceną rozpowszechnienia dysfunkcji seksualnych u osób uzależnionych od alkoholu: dostępnych jest niewiele badań, które zazwyczaj są oparte na niewielkiej populacji badanych, a te które już są dostępne, nie uwzględniają współistnienia różnych chorób w tej grupie pacjentów $[4,18]$.

Niemniej jednak postanowiliśmy je przytoczyć w celu przedstawienia charakterystyki poszczególnych dysfunkcji seksualnych z kategorii F.52 oraz ukazania skali problemu. Poniżej przedstawiona klasyfikacja według ICD-10 wydaje się także odpowiednia, ze względu na jej uniwersalność, gdyż bardzo często można spotkać się z różnymi podziałami i klasyfikacjami zaburzeń według różnych towarzystw.

\section{F52.0 - Brak lub utrata potrzeb seksualnych}

Brak potrzeb seksualnych jest tu objawem podstawowym, a nie wtórnym w stosunku do innych problemów seksualnych, takich jak zaburzenia erekcji czy dyspareunia [16]. Odsetek pacjentów uzależnionych od alkoholu, których dotyczy to schorzenie waha się od 36\% do $70 \%$. $[4,18]$

\section{F52.1 - Awersja seksualna i brak przyjemności seksualnej}

Perspektywie kontaktu seksualnego towarzyszy lęk tak silny, że pacjent unika aktywności seksualnej (awersja) lub reakcje seksualne przebiegają normalnie, orgazm jest osiągany, ale pacjent nie przeżywa adekwatnej przyjemności (brak seksualnej przyjemności) [16]. Szacuje się, że zaburzenie to dotyczy około $15 \%$ mężczyzn uzależnionych od alkoholu [18].

\section{F52.2 - Brak reakcji genitalnej}

Szacuje się, że brak reakcji genitalnej dotyczy około 33\% osób uzależnionych od alkoholu [15]. Definiowana jest ona jako stała lub nawracająca, częściowa lub całkowita niemożność osiągnięcia lub utrzymania wzwodu aż do zakończenia stosunku seksualnego [16]. U osób borykających się z zależnością (uzależnieniem) od alkoholu i zaburzeniami erekcji obserwuje się częściej problemy z osiągnięciem erekcji (59.3\%) niż z jej utrzymaniem $(40,6 \%)$ [18]. Ponadto w badaniu przeprowadzonym przez Arackala i wsp. można odnaleźć informacje, że u $8 \%$ badanych pacjentów występuje orgazm podczas gdy erekcja nie jest utrzymana [18].

\section{F52.3 - Zaburzenia orgazmu}

Do tej grupy zalicza się zaburzenia seksualne w przebiegu, których orgazm nie występuje, albo jest opóźniony [16]. Wśród osób uzależnionych od alkoholu rozpowszechnienie tego zaburzenia szacuje się od $10 \%$ do $25 \%[4,18]$ 


\section{F52.4 - Wytrysk przedwczesny}

Mianem tym określa się niezdolność do kontrolowania wytrysku w stopniu zapewniającym obu partnerom satysfakcjonujący stosunek seksualny [16]. Jest to najczęściej występująca dysfunkcja seksualna występująca wśród osób uzależnionych, a jej występowanie szacuje się od 38\% do nawet $86 \%$. [4, 18].

\section{F52.6 - Dyspareunia nieorganiczna}

Dyspareunia (ból w czasie stosunku) występuje zarówno u kobiet, jak i u mężczyzn. Często jest spowodowana miejscowym stanem patologicznym i powinna być wówczas odpowiednio zakwalifikowana [16]. Rozpoznaniem dyspareunii nieorganicznej posługujemy się tylko wtedy, gdy nie stwierdza się innej pierwotnej dysfunkcji seksualnej. Jest to najrzadziej występująca dysfunkcja seksualna, która występuje u około $6 \%$ pacjentów uzależnionych od alkoholu $[4,18]$.

W badaniu Arackala i Benegala wykazano, że 48\% badanych zgłaszało więcej niż jedną dysfunkcję seksualną [18]. Co ciekawe wykazano w tym badaniu liniową korelację między ilością spożywanego alkoholu przez badanych, a liczbą występujących dysfunkcji seksualnych. Zależność występowania dysfunkcji seksualnych od ilości spożywanego alkoholu widać także w badaniach Van Thiela i Lestera [19].

\section{Choroby towarzyszące uzależnieniu od alkoholu i ich} związek z dysfunkcjami seksualnymi

\subsection{Choroby somatyczne Nadciśnienie tętnicze}

Analizując choroby, których występowanie zwiększa ryzyko wystąpienia (pojawienia się) dysfunkcji seksualnych możemy wyróżnić takie zaburzenia, do wystąpienia których determinuje nadużywanie alkoholu(które determinowane są nadużywaniem alkoholu). Przykładem takiej choroby jest nadciśnienie tętnicze. W literaturze podmiotu brane są pod uwagę liczne hipotezy w jakim mechanizmie alkohol przyczynia się do rozwoju nadciśnienia tętniczego: indukcja nadciśnienia w wyniku oddziaływania alkoholu na centralny układ nerwowy [20], zmniejszenie odruchów z baroreceptorów [21], zwiększenie napięcia (aktywności) układu współczulnego [22], nadmiernego pobudzenia aktywności układu renina-angiotensyna-aldosteron [2325], zwiększenie stężenia kortyzolu u osób nadużywających alkoholu [26, 27], zwiększenie wewnątrzkomórkowego stężenia jonów wapnia $(\mathrm{Ca} 2+)[28]$, zaburzenia w funkcji śródbłonka naczyń [29]. W kontekście naszej pracy najciekawsza wydaję się ostatnia hipoteza. Zakłada ona, że alkohol zwiększa syntezę angiotensyny II mającej działanie wazokonstrykcyjne oraz hamuje aktywność śródbłonkowej syntazy tlenku azotu (eNOS). W wyniku tych mechanizmów dochodzi do zwężenia naczyń krwionośnych oraz wzrostu ciśnienia tętniczego [29 - 32]. Hipoteza ta stanowi punkt wspólny z hipotezą rozwoju dysfunkcji seksualnej u osób uzależnionych od alkoholu jako zaburzenia syntezy NO przez śródbłonek naczyń prącia. Sama zależność między dysfunkcją seksualną, a nadciśnieniem tętniczym jest też interesująca. Nawet $68 \%$ pacjentów mających zbyt wysokie ciśnienie tętnicze ma dysfunkcje seksualne[33-36], a występowanie dysfunkcji seksualnych jest potencjalnym czynnikiem predykcyjnym niekorzystnych incydentów sercowo-naczyniowych u pacjentów z grupy wysokiego ryzyka[37]. Ponadto, spożycie alkoholu wykazuje dodatnią linijną korelację ze wzrostem ryzyka zagrożenia rozwinięcia się nadciśnienia tętniczego [38]. Według wytycznych Polskiego Towarzystwa Nadciśnienia Tętniczego spożycie czystego etanolu nie powinno przekraczać granicy od 20 do $30 \mathrm{~g}$ (2-3 standardowe dawki alkoholu) u mężczyzn dziennie [39]. Biorąc pod uwagę już wcześniej przytoczone doniesienia Van Thiela i Lestera[19], widać, że przekroczenie dziennego spożycia 30 g czystego etanolu dziennie częściej predysponuje do rozwinięcia się zarówno nadciśnienia tętniczego jak i dysfunkcji seksualnych. Niestety brakuje badań obejmujących jednocześnie oba te elementy jako czynniki predykcyjne rozwoju dysfunkcji seksualnych u osób uzależnionych od alkoholu. Z tego też powodu trudno jest określić, czy istnieje zależność między rozwojem dysfunkcji seksualnych u mężczyzn uzależnionych od alkoholu jednocześnie chorujących na nadciśnienie.

\section{Cukrzyca}

Cukrzyca typu 2 jest chorobą zaburzającą prawidłową przemianę glukozy $\mathrm{w}$ organizmie. Odpowiedzialna za to jest zmniejszona wrażliwość mięśni i innych tkanek na insulinę, z którą wiąże się upośledzona sekrecja insuliny przez komórki $\beta$ trzustki. [40]. Cukrzyca odpowiedzialna jest za rozwój wielu chorób takich jak chociażby nefropatię i retinopatię cukrzycową, a także przyczynia się do rozwoju dysfunkcji seksualnych (w wyniku występujących w cukrzycy zmian naczyniowych, ale przede wszystkim neuropatii)[41]. Dysfunkcje seksualne dotyczą około 50$70 \%$ osób chorujących na cukrzycę typu 2 [42] Jednocześnie ciężkie nadużywanie alkoholu predysponuje do rozwoju cukrzycy[43]. Ciąg przyczynowo skutkowy wygląda podobnie jak w przypadku nadciśnienia tętniczego: alkohol jednocześnie sam powoduje dysfunkcje seksualne, a jednocześnie predysponuje do wystąpienia chorób, które mogą powodować dysfunkcje seksualne. Póki co jes to tylko hipoteza, gdyż brakuje badań potwierdzających występowanie takowych zależności.

\section{Marskość wątroby}

Związek między nadużywaniem alkoholu, a marskością 
wątroby jest powszechnie znany. Jak wynika z badania Rehma i wsp. spożycie alkoholu powyżej 3 standardowych dawek alkoholu (liczonych w przeliczeniu 1 dawka $=12 \mathrm{~g}$ etanolu) znacząco wpływa na rozwój marskości wątroby[44]. Z innego badania przeprowadzonego przez Sherlocka i wsp., marskość wątroby dotyczy około 77\% nadużywających alkoholu [45]. Uszkodzenie wątroby przez alkohol jest związane $\mathrm{z}$ jej zdolnością do metabolizmu etanolu. Jest on dwukrotnie utleniany (początkowo do aldehydu octowego, a następnie do kwasu octowego), czemu towarzyszy gromadzenie się dużej ilości zredukowanej formy NAD (NADH), co z kolei zaburza potencjał oksydacyjny i metaboliczny wątroby. Nadmiar NADH promuje syntezę i odkładanie triglicerydów w wątrobie. Doprowadza to do rozwoju pierwszego stadium alkoholowej choroby wątroby, jakim jest jej stłuszczenie [46 - 48]. Następnie, w wyniku kontynuowania chronicznego przyjmowania etanolu, dochodzi do przewlekłego zapalenia wątroby (stadium 2), co skutkuje włóknieniem narządu i w końcowym etapie może doprowadzić do jej marskości (stadium 3) [49]. Marska wątroba, przyczynia się do rozwoju innych schorzeń w tym do dysfunkcji seksualnych, których rozpowszechnienie w tej grupie pacjentów szacuje się na około 51\% [50]. Jest to konsekwencja niewydolności metabolicznej wątroby, która objawia się w 3 aspektach. Po pierwsze niewydolność metaboliczna narządu skutkuje akumulacją szkodliwych substancji (w tym alkoholu i jego metabolitów), które bezpośrednio uszkadzają podwzgórze, przysadkę oraz gonady. Po drugie hiperestrogenizm i zmniejszony stosunek androgenów do estrogenów będący wynikiem niewydolności krążenia wrotnego oraz zwiększonej konwersji androgenów do estrogenów na obwodzie. Po trzecie upośledzona synteza albumin w wątrobie, czego konsekwencją jest niedobór białek niezbędnych do syntezy hormonów przedniego płata przysadki [51-54]. Z tych powodów u osób leczonych z powodu alkoholowej marskości wątroby stwierdza się widoczne obniżenie testosteronu w surowicy[55].

Ciąg przczynowo - skutkowy między szkodliwym używaniem alkoholu, marskością wątroby oraz dysfunkcjami seksualnymi wydaje się być póki co najlepiej udokumentowany w literaturze.

\section{Choroby neurologiczne}

Kolejną grupą schorzeń występujących u osób uzależnionych od alkoholu są choroby neurologiczne, wśród których możemy wyróżnić 2 (dwie) główne grupy chorób: polineuropatię alkoholową oraz encefalopatie alkoholowe (encefalopatia alkoholowa Wernickiego, encefalopatia alkoholowa Morela, czy mielinoza środkowa mostu) [56]. Etiologia tych schorzeń związana jest z niedoborami tiaminy na braki której składają się 3 czynniki: niedostateczna podaż, upośledzenie wchłaniania w jelicie cienkim oraz niewydolność funkcjonalna wątroby (w wyniku której tiamina jest jest fosforylowana do swojej formy aktywnej) [57]. Warto także podkreślić, że polineuropatia jest także jednym z częstych powikłań cukrzycy, która jak już zostało opisane, częściej występuje u osób spożywających nadmierne ilości alkoholu. Dodatkowo u osób, które odstawiły alkohol możliwe jest wystąpienie drgawkowych napadów abstynencyjnych (tzw. „padaczka alkoholowa”). Patomechanizm drgawek upatruje się w zmniejszonej czułości receptorów GABA-ergicznych oraz zwiększeniu aktywności układu aminokwasów pobudzających (receptory NMDA) [58, 59].

Wykazano, że neuropatie, czy padaczka są czynnikami mogącymi predysponować do zaburzeń seksualnych [60]. Rozpowszechnienie neuropatii wśród osób uzależnionych od alkoholu szacuje się na około od 25 do 66\% [61]. Wynika stąd wniosek, że u części uzależnionych od alkoholu mężczyzn rozwoju dysfunkcji seksualnych można upatrywać w neuropatii rozwiniętej na podłożu nadmiernego spożycia alkoholu.

W kontekście zaburzeń neurologicznych warto także wspomnieć o typie IV typologii uzależnienia alkoholowego według Lescha. Opisuje on wykształcenie się uzależnienia od alkoholu u osób z urazami ośrodkowego układu nerwowego powstałymi w okresie np. okołoporodowym, czy wczesnego dzieciństwa [62,63]. Chorobami towarzyszącymi tym urazom są chociażby neuropatie, czy padaczka. Osoby te łatwo ulegają wpływom środowiska, proces decyzyjny jest u nich upośledzony, a procesy poznawcze zaburzone. Biorąc pod uwagę ten typ uzależnienia możliwe jest, że urazy układu nerwowego we wczesnym okresie rozwoju stanowią wspólną przyczynę rozwoju dysfunkcji seksualnych oraz uzależnienia od alkoholu u części pacjentów.

\subsection{Zaburzenia psychiczne Zaburzenia depresyjne}

W typologii uzależnienia alkoholowego według Lescha wyróżnia się 4 typy uzależnienia ze względu na przyczyny sięgania po alkohol, obraz zespołu abstynencyjnego oraz zalecane formy terapii[64]. W kontekście tematu niniejszej pracy należy zwrócić szczególną uwagę na typ III, który opisuje model "alkoholu jako antydepresantu", nazywany także "objawowym", "psychiatrycznym", czy też "psychotycznym" [63]. Charakteryzuje on osoby sięgające po alkohol w celach samoleczenia objawów psychopatologicznych towarzyszących najczęściej stanom depresyjnym. W literaturze można zauważyć istotną różnicę w rozpowszechnieniu zaburzeń seksualnych u osób chorujących na depresję (59/1000 osób) w porównaniu do osób zdrowych (37/1000)[65]. Warto także w tym miejscu wspomnieć o wzajemnej korelacji między depresją, a dysfunkcjami seksualnymi. Seagraves w swoich badaniach 
zauważa, że zarówno występowanie depresji prowadzi do występowania dysfunkcji seksualnych, jak i odwrotnie; u niektórych pacjentów obserwowano wystąpienie depresji, której pojawienie upatrywano w występujących dysfunkcjach seksualnych[66]. Dodatkowo, w przebiegu uzależnienia od alkoholu często u pacjentów rozwija się epizod depresyjny, który może przyczyniać się do rozwoju dysfunkcji seksualnych [67]. Obserwacje te wydają się istotne z dwóch powodów. Po pierwsze możliwe jest, że dysfunkcja seksualna u osób uzależnionych reprezentujących III typ klasyfikacji według Lescha może być raczej spowodowana zaburzeniami depresyjnymi niż samym toksycznym działaniem alkoholu. Po drugie uzależnienie może być skutkiem "samoleczenia" towarzyszącemu zaburzeniu depresyjnemu. Z kolei rozwój zaburzenia depresyjnego może być wynikiem występujących u pacjenta dysfunkcji seksualnych. Jednakże hipoteza ta póki co nie znalazła potwierdzenia $\mathrm{w}$ badaniach naukowych ze względu na ograniczone piśmiennictwo poświęcone temu problemowi. Z doniesień interesujące wydają się także badania Kima i Oha, którzy donoszą, że u osób u których źródłem dysfunkcji seksualnych jest strona psychiczna, w surowicy stwierdza się podwyższony poziom noradrenaliny, jednakże nie ma badań potwierdzających, czy zależność ta ma to odzwierciedlenie u osób nadużywających alkohol[68]. Niewykluczone jest, że w przyszłości ocena stężenia osoczowej noradrenaliny może pomóc w diagnostyce dysfunkcji seksualnych, których podłoże upatruję się w zaburzeniach psychicznych.

Kolejnym aspektem ważnym w III typie uzależnienia alkoholowego są występujące $\mathrm{w}$ tym typie zaburzenia snu. Jest to także istotny problem, który zdaje się narastać u osób leczonych odwykowo, gdzie odsetek pacjentów z zaburzeniami snu, zależnie od charakterystyki grupy, wynosi od 36 do $72 \%[69]$. Jest to ważna obserwacja, gdyż zaburzenia snu także predysponują do zaburzeń seksualnych [70]. Dodatkowo same zaburzenia snu mogą prowadzić do rozwinięcia się zależności od alkoholu, które w mechanizmie błędnego koła dalej pogłębiają zaburzenia snu. Z tych właśnie powodów istotne wydaje się zwrócenie uwagi na sen u pacjentów uzależnionych od alkoholu, gdyż zaburzenia snu mogą być powodem rozwoju zarówno uzależnienia od alkoholu jak i dysfunkcji seksualnych [71 - 74].

\section{Zaburzenia lękowe}

Typ II typologii uzależnia alkoholowego według Lescha nazywany "modelem lęku", "neurotycznym", "lękowym", charakteryzuje osoby spożywające alkohol w celu zmniejszenia poczucia lęku[63,75]. Częstość występowania tego typu uzależnienia jest ciężka do oszacowania i uważa się, że w populacji osób uzależnionych od alkoholu występowanie lęku uogólnionego może oscylować w granicach od 3 do 52\%[76]. Ponadto pacjenci reprezentujący II typ uzależnienia według Lescha charakteryzują się niską samooceną i słabo rozwiniętym ego [62]. Po przeanalizowaniu dostępnej literatury można wysunąć hipotezę, że zaburzenia seksualne u osób nadużywających alkoholu zaliczonych do typu III jak II wykazują duże podobieństwo. Podobnie jak w typie III, w typie II można wysunąc hipotezy, że lęk jest zarówno przyczyną rozwinięcia się zależności od alkoholu jak i dysfunkcji seksualnych, albo, że wystąpienie dysfunkcji seksualnych jest jednym z czynników mających wpływ na rozwinięcie się zaburzeń lękowych, a w dalszej perspektywie i zależności od alkoholu. [77]. W badaniach Arackala i Benegala możemy odnaleźć, że 19.79\% badanych stwierdziło niezadowolenie z własnych funkcji seksualnych [18]. Aczkolwiek ze względu na ograniczony zakres przeprowadzonych badań ciężko określić na ile zgłaszane niezadowolenie miało odbicie $\mathrm{w}$ faktycznych problemach, a na ile w niskiej samoocenie, która występuje w tym typie uzależnienia od alkoholu.

\section{Podsumowanie}

Zalecane obecnie w medycynie podejście holistyczne powinno znaleźć swój wymiar w diagnostyce i leczeniu dysfunkcji seksualnych u mężczyzn uzależnionych od alkoholu. Po pierwsze brakuje badań na temat dysfunkcji seksualnych u osób uzależnionych od alkoholu obciążonych dodatkowymi chorobami współwystępującymi. Przeprowadzona przez nas analiza badań nasuwa przypuszczenia, że problem dysfunkcji może być powiązany z alkoholem w dwóch aspektach. Po pierwsze dysfunkcje mogą być wynikiem bezpośredniego szkodliwego działania alkoholu, a po drugie mogą być konsekwencją choroby, do której predysponowała nadmierna konsumpcja alkoholu. Ponadto istnieje potrzeba dokładnej diagnostyki dysfunkcji seksualnych u osób, których uzależnienie możemy zaliczyć do II, lub III typu uzależnienia według Lescha. Możliwe jest, że u takich pacjentów depresja oraz lęk są pierwotnymi zaburzeniami, które przyczyniają się do rozwoju dysfunkcji seksualnych jak i uzależnienia od alkoholu. Prawdopodobną hipotezą wydaje się także być to, że część pacjentów, których można zakwalifikować do II i III typu według Lescha rozwój uzależnienia od alkoholu jest skutkiem pierwotnych dysfunkcji seksualnych, w mechanizmie którego pośrednią rolę odgrywa depresja oraz lęk. Jednakże tak jak zostało stwierdzone wyżej, żeby potwierdzić tę hipotezę trzeba przeprowadzić bardziej kompleksowe badania na ten temat.

Wspominając holistyczne podejście warto także wziąć pod uwagę leczenie chorób współistniejących u osób uzależnionych od alkoholu $\mathrm{z}$ dysfunkcjami seksualnymi. Warto w praktyce klinicznej pamiętać, że część leków stosowanych w leczeniu nadciśnienia tętniczego może 
pogłębiać problem u takich osób. Z badań wynika, iż $\beta$-blokery, tiazydy i blokery kanałów wapniowych częściej powodują problemy z erekcją niż inhibitory konwertazy, czy blokery receptorów angiotensyny [78]. Obiecująco wyglądają także doniesienia na temat tadanafilu. W przeprowadzanych badaniach obserwuje się polepszenie funkcji seksualnych u osób z alkoholową marskością wątroby [79]. Podobnie wygląda sytuacja wśród leków psychotropowych, szczególnie z grupy SSRI. Biorąc pod uwagę, że pacjenci, których można zaklasyfikować do typu II i III uzależnienia charakteryzują się współwystępowaniem lęku i depresji trzeba w ich leczeniu wziąć pod uwagę właśnie dysfunkcje seksualne. Dlatego, zgodnie z dostępnymi badaniami wydaje się, że lepszą alternatywą niż leki z grupy SSRI, (gdzie dysfunkcje seksualne dotyczą od 30 do $60 \%$ pacjentów) są takie leki jak buspiron, czy nefazodon, gdzie występowanie takich dysfunkcji dotyczy mniej niż 10\% leczonych [80].

\section{Wnioski}

1. Uzależnienie od alkoholu związane jest z występowaniem różnych rodzajów dysfunkcji seksualnych.

2. W diagnozie DS należy brać pod uwagę wszystkie możliwe przyczyny mogące doprowadzić do rozwoju DS w tej grupie pacjentów, między innymi współwystępowanie chorób somatycznych czy negatywny wpływ leków na funkcje seksualne.

3. Występowanie DS jest związane z wyższym ryzykiem przerwania abstynencji od alkoholu.

4. Istnieje potrzeba przeprowadzenia większej liczby badań w celu lepszego zrozumienia związku pomiędzy uzależnieniem od alkoholu a występowaniem zaburzeń seksualnych.

\section{Conflict of interest}

The authors have declared no conflict of interest.

\section{References}

1. Zgliczyński SW. Alkohol w Polsce. Infos 2016; 215.

2. Nutt DJ, King AL, Phillips LD. Drug harms in the UK: a multicriteria decision analysis. Lancet 2010; 376: 1558-1565.

3. Wylie KR, Steward D, Seivewright N, Smith D. Prevalence of sexual dysfunction in three psychiatric outpatient settings: A drug misuse service, an alcohol misuse service and a general adult psychiatry clinic. Sex Relat Ther, 2002; 17:149-60.

4. Grinshpoon A, Margolis A, Weizman A, Ponizovsky AM. Sildenafil citrate in the treatment of sexual dysfunction and its effect on quality of life in alcohol dependent men: Preliminary findings. Alcohol Alcohol 2007; 42:340-346.

5. Paparriropoulos T, Zabelis T, Tzavellas E, Karaiskos D, Zaloni R, Stachtea1 X, et al. Sexual dysfunction and alcohol abuse. Eur Neuropsychopharmacol 2009; 19:6-7.

6. Dissiz M, Oskay ÜY. Evaluation of sexual functions in Turkish alcohol-dependent males. J Sex Med 2011; 8:3181-3187.

7. Vijayasenan ME. Alcohol and sex. N Z Med J. 1981; 93:18-20.

8. Grover S, Mattoo SK, Pendharkar S, Kandappan V. Sexual Dysfunction in Patients with Alcohol and Opioid Dependence.
Indian Journal of Psychological Medicine 2014; 36:355-365.

9. Lue TF. Erectile dysfunction. N Engl J Med 2000; 342:1802-1813.

10. Prieto D. Physiological regulation of penile arteries and veins. Int J Impot Res 2008; 20:17-29.

11. Cicero TJ. Alcohol-induced deficits in the hypothalamic-pituitaryleteinizing hormone axis in the male. Alcohol Clin Exp Res 1982; 6:207-215.

12. Salonen I, Pakarinen P, Huhtaniemi I. Effect of chronic ethanol diet on expression of gonadotropin genes in the male rat. J Pharmacol Exp Ther 1992; 260:463-467.

13. Little PJ, Adams ML, Cicero TJ. Effects of alcohol on the hypothalamic-pituitary-gonadal axis in the developing male rat. J Pharmacol Exp Ther 1992; 263:1056-1061.

14. Emanuele NV, LaPagli N, Steiner J, Colantoni A, Van Thiel DH, Emanuele MA. Peripubertal paternal EtOH exposure. Endoctine 2001; 14:213-219.

15. Anderson RA Jr, Quigg JM, Oswald C, Zaneveld LJ. Demonstration of a function blood-testis barrier to acetaldehyde. Evidence for lack of acetaldehyde effect on ethanol-induced depression of testosterone in vivo. Biochem Pharmacol 1985; 34:685-695.

16. Pużyński S, Wciórka J, red. Klasyfikacja zaburzeń psychicznych i zaburzeń zachowania w ICD-10. Opisy kliniczne i wskazówki diagnostyczne. Uniwersyteckie Wydawnictwo „Versalius”, Instytut Psychiatrii i Neurologii; Kraków-Warszawa; 1997.

17. Święcicki $Ł$, Gałecki P red. Kryteria diagnostyczne z DSM-5, Desk Reference Amerykańskie Towarzystwo Psychiatryczne. Edra Urban \& Partner, 2015.

18. Arackal BS, Benegal V. Prevalence of sexual dysfunction in male subjects with alcohol dependence. Indian J Psychiatry 2007; 492:109-112.

19. Van Thiel DM, Lester R. The effect of chronic alcohol abuse on sexual function. Clin Endocrinol Matab 1979; 8:499-510.

20. Alcohol and hypertension--implications for management. A consensus statement by the World Hypertension League. J Hum Hypertens 1991; 5:227-232.

21. Grassi G. Sympathetic and baroreflex function in hypertension: implications for current and new drugs. Curr Pharm Des. 2004; 10:3579-3589.

22. Russ R, Abdel-Rahman AR, Wooles WR. Role of the sympathetic nervous system in ethanol-induced hypertension in rats. Alcohol. 1991; 8:301-307.

23. Jing L, Li WM, Zhou LJ, Li S, Kou JJ, Song J. Expression of reninangiotensin system and peroxisome proliferator-activated receptors in alcoholic cardiomyopathy. Alcohol Clin Exp Res. 2008; 32:1999-2007.

24. Ibsen H, Christensen NJ, Rasmussen S, Hollnagel H, Damkjaer Nielsen M, Giese J. The influence of chronic high alcohol intake on blood pressure, plasma noradrenaline concentration and plasma renin concentration. Clin Sci (Lond) 1981; 61:377-379.

25. Soardo G, Donnini D, Moretti M, Milocco C, Catena C, Sechi LA. Effects of antihypertensive drugs on alcohol-induced functional responses of cultured human endothelial cells. Hypertens Res. 2008; 31:345-351.

26. Potter JF, Watson RD, Skan W, Beevers DG. The pressor and metabolic effects of alcohol in normotensive subjects. Hypertension. 1986; 8:625-631.

27. Bannan LT, Potter JF, Beevers DG, Saunders JB, Walters JR, Ingram MC. Effect of alcohol withdrawal on blood pressure, plasma renin activity, aldosterone, cortisol and dopamine beta-hydroxylase. Clin Sci (Lond) 1984; 66:659-663.

28. Wakabayashi I, Hatake K, Hishida S. Ethanol inhibits intra- and extracellular $\mathrm{Ca}(2+)$-dependent contraction of rat aorta by different mechanisms. Nihon Arukoru Yakubutsu Igakkai Zasshi. 1998; 
33:273-286.

29. Husain K, Vazquez M, Ansari RA, Malafa MP, Lalla J. Chronic alcoholinduced oxidative endothelial injury relates to angiotensin II levels in the rat. Mol Cell Biochem. 2008; 307:51-58.

30. Pinardi G, Brieva C, Vinet R, Penna M. Effects of chronic ethanol consumption on alpha-adrenergic-induced contractions in rat thoracic aorta. Gen Pharmacol. 1992; 23:245-248.

31. Puddey IB, Zilkens RR, Croft KD, Beilin LJ. Alcohol and endothelial function: a brief review. Clin Exp Pharmacol Physiol. 2001; 28:1020-1024.

32. Slomiany BL, Piotrowski J, Slomiany A. Alterations in buccal mucosal endothelin-1 and nitric oxide synthase with chronic alcohol ingestion. Biochem Mol Biol Int. 1998; 45:681-688.

33. Nunes KP, Labazi H, Webb RC. New insights into hypertensionassociated erectile dysfuntion. Curr Opin Nephrol Hypertens 2012; 21:163-70.

34. Virag R, Bouilly P, Frydman D. Is impotence an arterial disorder? A study of arterial risk factors in 440 impotent men. Lancet 1985; 1:181-84.

35. Mittawae B, El-Nashaar AR, Fouda A, Magdy M, Shamloul R. Incidence of erectile dysfunction in 800 hypertensive patients: a multicenter Egyptian national study. Urology 2006; 67:575-78.

36. Burchardt M, Burchardt T, Baer L, et. al. Hypertension is associated with severe erectile dysfunction. J Urol 2000; 164: 1188-1191.

37. Böhm M, Baumhäkel M, Teo K, Sleight P, Probstfield J, Gao P, Mann JF, Diaz R, Dagenais GR, Jennings GL, Liu L, Jansky P, Yusuf $\mathrm{S}$, for the ONTARGET/TRANSCEND Erectile Dysfunction Substudy Investigators. Erectile dysfunction predicts cardiovascular events in high-risk patient receiving telmisartan, ramipril, or both: The ongoing Telmisartan Alone and in combination with Ramipril Global Edpoint Trial/Telmisartan Randomized Assssment Study in ACE intolerant subjects with cardiovascular disease (ONTARGET/ TRANSCEND) Trials. Circulation 2010; 121: 1439-1446.

38. Taylor B, Irving HM, Baliunas D, Roerecke M, Patra J, Mohapatra $\mathrm{S}$, Rehm J. Alcohol and hypertension: gender differences in doseresponse relationships determined through systematic review and meta-analysis. Addiction. 2009; 104:1981-1990.

39. Tykarski A., Narkiewicz K., Gaciong Z. Zasady postępowania w nadciśnieniu tętniczym - 2015 rok. Wytyczne Polskiego Towarzystwa Nadciśnienia Tętniczego. Nadciśnienie Tętnicze w Praktyce 2015; 1: 1-70.

40. Lin Y, Sun Z. Current views on type 2 diabetes. J Endocrinol 2010; 204:1-11.

41. Ponholzer A, Temml C, Mock K, Marszalek M, Obermayr R, Madersbabacher S. Prevalence and risk factors for erectile dysfunction in 2869 men using a validated questionnaire. Eur Urol 2005; 47: 80-86.

42. Lewis RW, Fugk Meyer KS, Corona G, et. al. Definitions/ epidemiology/risk factors for sexual dysfunction. J Sex Med 2010; 7:1598-1607.

43. Wannamethee SG, Shaper AG, Perry IJ, Alberti KG. Alcohol consumption and the incidence of type II diabetes. J Epidemiol Community Health 2002; 56:542-548.

44. Rehm J, Taylor B, Mohapatra S, Irving H, Baliunas D, Patra J, Roerecke $\mathrm{M}$. Alcohol as a risk factor for liver cirrhosis: A systematic review and meta-analysis. Drug and Alcohol Review, 2010; 29:437-445.

45. Sherlock S. Alcohol liver disease. Lancet, 1995; 345:227-234.

46. Cubero FJ, Nieto N. Kupffer cells and alcoholic liver disease. Rev. Esp. Enferm. Dig., 2006; 98: 460-472.

47. Furukawa F, Matsuzaki K, Mori S, Tahashi Y, Yoshida K, Sugano Y, Yamagata H, Matsushita M, Seki T, Inagaki Y., Nishazawa M., Fujisawa J., Inoue K.: p38 MAPK mediates fibrogenic signal throught Smad3 phosphorylation in rat myofi broblasts. Hepatology, 2003;
38: 879-889.

48. Lieber CS. Ethanol metabolism, cirrhosis and alcoholism. Clin. Chim. Acta, 1997; 257: 59-84.

49. Cichoż - Lach H, Grzyb M, Celiński K, Słomka M. Nadużywanie alkoholu a alkoholowa choroba wątroby. Alkoholizm i Narkomania 2008; 21:55-62.

50. Simsek I, Aslan G, Akarsu M, Koseoglu H, Esen A. Assessment of sexual functions in patients with chronic liver disease. International Journal of Impotence Research, 2005; 17:343-345.

51. Bannister P, Handley T, Chapman C, Losowski MS. Hypogonadism in chronic liver disease: impaired release of luteinising hormone. Br Med J 1986; 293:1191-1193.

52. Galvaõ-Teles A, Monteiro E, Gavaler JS. Gonadal consequences of alcohol abuse: lessons from the liver. Hepatology 1986; 6: 135-140.

53. Guechot J, Vaubourdolle M, Ballet F, Giboudeau J, Darnis F, Poupon R. Hepatic uptake of sex steroids in men with alcoholic cirrhosis. Gastroenterology 1987; 92: 203-207.

54. Pajarinen JT, Karhunen PJ. Spermatogenic arrest and 'Sertoli cellonly' syndrome-common alcohol-induced disorders of the human testis. Int J Androl 1994; 17:292-299.

55. Morgan MY. Sex and alcohol. Br Med Bull 1982; 38:43-48.

56. Kozielewicz D, Dybowska D, Holota W. Wybrane aspekty kliniczne nadużywania alkoholu. Medical Science Review - Hepatologia 2011; 11:115-117.

57. Singleton CK, Martin PR. Molecular mechanisms of thiamine utilization. Curr Mol Med 2001; 1: 197-207.

58. Nevo I, Hamn M. Neurotransmitter and neuromodulatory mechanism involved in alcohol abuse and alcoholism. Neurochem. Int. 1995; 26:305.

59. Tsai GE, Ragan $P$, Chang $R$, et al.: Increased glutamatergic neurotransmission and oxidative stress after alcohol withdrawal. Am. J. Psychiatry 1998; 155:726.

60. Siddiqui MA, Peng B, Shanmugam N, et al. Erectile dysfunction in young surgically treated patients with lumbar spine disease: a prospective follow-up study. Spine 2012; 37:797-801.

61. Valls-Solé J, Nicolás J, Villalta J, Urbano-Marquez A. Autonomic and peripheral neuropathies in patients with chronic alcoholism. A dose-related toxic effect of alcohol. Arch Neurol 1995; 52: 45-51.

62. Kogoj D, Lesch O, Walter H. Lesch Alcoholism Typology Medical Treatment and Research. Arch Pschychiatr Psychother 2010; 12:37-48.

63. Woronowicz BT. Uzależnienia. Geneza, terapia, powrót do zdrowia. Warszawa; Wydawnictwo Edukacyjne PARPAMEDIA:2009.

64. Lesch O, Dietzel M, Walter H, Zailer K. The course of alcoholism. Long-term prognosis in different types. Forensic Science International 1988; 36:121-138.

65. Shiri R, Koskimäki J, Tammela TL, Häkkinen J, Auvinen A, Hakama M. Bidirectional relationship between depression and erectile dysfunction. J Urol 2007; 177:669-673.

66. Seagraves RT. Depression and erectile dysfunction. Postgrad Med 2000; 107:24-7.

67. Fergusson DM, Boden JM, Horwood LJ. Tests of Causal Links Between Alcohol Abuse or Dependence and Major Depression. Arch Gen Psychiatry 2009; 66:260-266.

68. Kim SC, Oh MM. Norephinephrine involvement in response to intracorporeal injection of papaverine in psychogenic impotance. J Urol 1992; 147:1530-1532.

69. Jakubczyk A, Wojnar J, Wojnar M, Klimkiewicz A, Brower K. Zaburzenia snu u osób uzależnionych od alkoholu. Alkoholizm i Narkomania, 2009; 22:143-159.

70. Hirshkowitz M, Karacan I, Arcasoy MO, Acik G, Narter EM, Williams RI. Prevalence of sleep apnea in men with erectile dysfunction. Urology 1990; 36:323-334. 
71. Stein MD, Friedmann PD. Disturbed sleep and its relationship to alcohol use. Substance Abuse 2006; 26:113.

72. Blumenthal SJ, Fine T. Sleep abnormalities associated with mental and addictive disorders: implications for research and clinical practice. Journal of Practical Psychiatry and Behavioral Health 1996; 2:67-79.

73. Vitiello MV. Sleep, alcohol, and alcohol abuse. Addiction Biology 1997; 2:151-158.

74. National Institute on Alcohol Abuse and Alcoholism. Alcohol and Sleep. Alcohol Alert 1998; 41

75. Lesch O, Walter H. Subtypes of alcoholism and their role in therapy. Alcohol 1996; 31: 63-67.

76. Wojnar M, Ślusarska A, Klimkiewicz A. Nawroty w uzależnieniu od alkoholu część 3: społeczno-demograficzne i psychologiczne czynniki ryzyka. Alkoholizm i Narkomania 2007; 20: 81-102.

77. Carson C, Dean J, Wylie M. Managment of erectile dysfunction in clinical practice. Springer Medical Publishing; New York; 2006.

78. Thomas A, Woodard C, Rovner ES, Wein AJ. Urologic complications of nonurologic medications. Urol Clin North Am 2003; 30:123-31.

79. Thakur J, Grover S, Rathi S, Chopra M, Taneja S, Duseja A, Chawla Y, Bhansali A, Dhiman RK. Tadalafil, a Phosphodiesterase-5 Inhibitor, Improves Erectile Dysfunction in Patients with Liver Cirrhosis Journal of Clinical and Experimental Hepatology 2016; 6:56-57.
80. Gregorian RS, Golden KA, Bahce A, Goodman C, Kwong WJ, Khan ZM. Antidepressant-induced sexual dusfunction. Ann Pharmacother 2002

\section{Correspondence address:}

Jakub Siembida

Student Research Group at the I Department of

Psychiatry, Psychotherapy and Early Intervention,

Medical University of Lublin, Głuska St. 1, 20-439

Lublin,

e-mail: jakub.siembida@gmail.com

Otrzymano: 10.05.2018

Zrecenzowano: 21.05.2018, 07.06.2018, 25.06.2018

Przyjęto do druku: 30.06.2018 